\title{
Notes on the vocalizations of Chubb's Cisticola (Cisticola chubbi)
}

Peter Boesman

In the following we briefly analyze and compare voice of the different races of Chubb's

Cisticola (Cisticola chubbi). We also try to quantify the extent of any vocal differences using the criteria proposed by Tobias et al. (2010), as a support for taxonomic review.

We have made use of sound recordings available on-line from Xeno Canto (XC).

Our main interest is to compare voice of the geographically disjunct western (adametzi and discolor)and eastern group (marungensis and nominate).

Comparison of song:

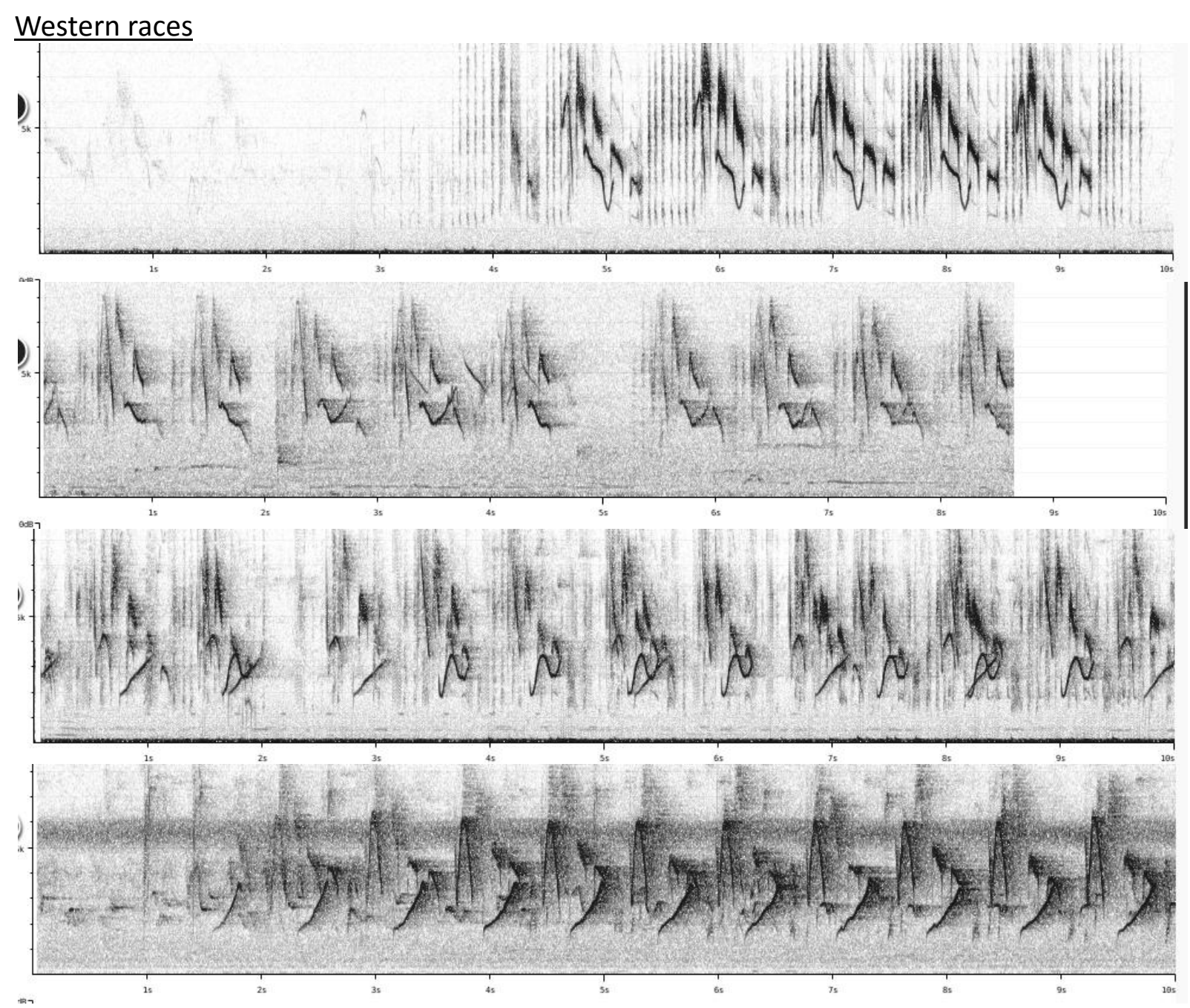




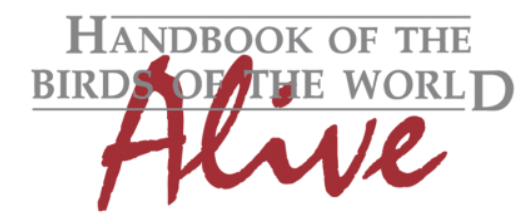

\section{ORNITHOLOGICAL NOTES}

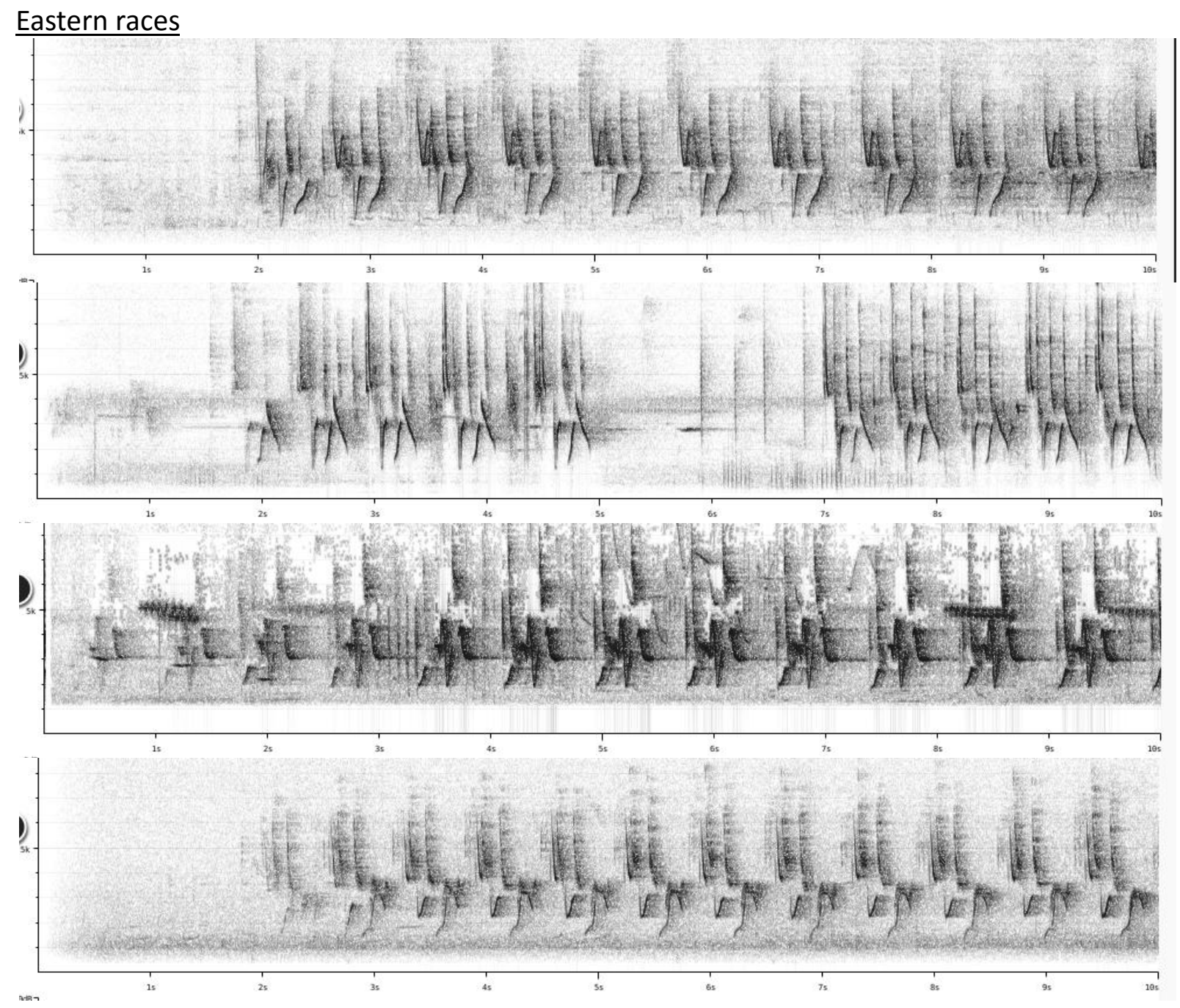

Song is a rhythmic phrase repeated at constant pace without clear pause in between phrases. The phrase typically starts with a few short notes and ends with a more melodious whistle, e.g. "chi-chi-weee-chi-chi-weee-chi-chi-weee..".

There is obviously quite some variation in song, but the basic structure is always the same (including basic sound parameters such as note length, pace and frequency range).

Some note shapes are possibly linked to certain races, but to confirm that we would need a much larger sample size. At this point, we can only conclude that there are no clear differences in voice.

This note was finalized on 10th February 2016, using sound recordings available on-line at that moment. We would like to thank in particular the sound recordists who placed their recordings for this species on XC: Jason Anderson, Michal Budka, Marcell Claassen, Brian Cox, Rolf de By, Josh Engel, David Moyer, Rory Nefdt, Mike Nelson, Tomasz Osiejuk and Martin StMichel. 


\section{References}

Tobias, J.A., Seddon, N., Spottiswoode, C.N., Pilgrim, J.D., Fishpool, L.D.C. \& Collar, N.J. (2010). Quantitative criteria for species delimitation. Ibis 152(4): 724-746.

\section{Recommended citation}

Boesman, P. (2016). Notes on the vocalizations of Chubb's Cisticola (Cisticola chubbi). HBW Alive Ornithological Note 225. In: Handbook of the Birds of the World Alive. Lynx Edicions, Barcelona. (retrieved from http://www.hbw.com/node/932186 on 8 September 2016). 